\title{
Diagnostic and therapeutic errors in trigeminal autonomic cephalalgias and hemicrania continua: a systematic review
}

\author{
Michele Viana ${ }^{1 *}$, Cristina Tassorelli ${ }^{1,2}$, Marta Allena ${ }^{1}$, Giuseppe Nappi ${ }^{1}$, Ottar Sjaastad ${ }^{3}$ and Fabio Antonaci ${ }^{1,2}$
}

\begin{abstract}
Trigeminal autonomic cephalalgias (TACs) and hemicrania continua $(H C)$ are relatively rare but clinically rather welldefined primary headaches. Despite the existence of clear-cut diagnostic criteria (The International Classification of Headache Disorders, $2^{\text {nd }}$ edition - ICHD-II) and several therapeutic guidelines, errors in workup and treatment of these conditions are frequent in clinical practice. We set out to review all available published data on mismanagement of TACs and HC patients in order to understand and avoid its causes. The search strategy identified 22 published studies. The most frequent errors described in the management of patients with TACs and $\mathrm{HC}$ are: referral to wrong type of specialist, diagnostic delay, misdiagnosis, and the use of treatments without overt indication. Migraine with and without aura, trigeminal neuralgia, sinus infection, dental pain and temporomandibular dysfunction are the disorders most frequently overdiagnosed. Even when the clinical picture is clear-cut, TACs and HC are frequently not recognized and/or mistaken for other disorders, not only by general physicians, dentists and ENT surgeons, but also by neurologists and headache specialists. This seems to be due to limited knowledge of the specific characteristics and variants of these disorders, and it results in the unnecessary prescription of ineffective and sometimes invasive treatments which may have negative consequences for patients. Greater knowledge of and education about these disorders, among both primary care physicians and headache specialists, might contribute to improving the quality of life of TACs and HC patients.
\end{abstract}

Keywords: Cluster headache, Paroxysmal hemicrania, SUNCT, Trigeminal autonomic cephalalgias, Hemicrania continua, Error, Pitfall, Misdiagnosis, Mismanagement

\section{Introduction}

The trigeminal autonomic cephalalgias (TACs) are a group of primary headache disorders that includes cluster headache $(\mathrm{CH})$, paroxysmal hemicrania $(\mathrm{PH})$, and short-lasting unilateral neuralgiform headache attacks with conjunctival injection and tearing/cranial autonomic features (SUNCT). Hemicrania continua $(\mathrm{HC})$ is a continuous unilateral headache form that, like $\mathrm{PH}$, is indomethacin-responsive. $\mathrm{HC}$ is included in group 4 of The International Classification of Headache Disorders, second edition (ICHD-II) [1]. However, this categorization is still debated and $\mathrm{HC}$ is often included with the TACs $[2,3]$. Moreover, some authors suggest that the two

\footnotetext{
* Correspondence: michele.viana@mondino.it

${ }^{1}$ Headache Science Center-C. Mondino National Institute of Neurology

Foundation, IRCCS, Via Mondino 2, Pavia 27100, Italy

Full list of author information is available at the end of the article
}

indomethacin-sensitive headaches should be in one group [4]. Compared with other primary headaches, the TACs have stereotypic features that, since they are defined in the ICHD-II diagnostic criteria [1], should, in principle, make them easily recognizable: short-lasting duration, unilateral pain location, and ipsilateral cranial autonomic symptoms (CAS). Up-to-date international therapeutic guidelines for these disorders [5] are also available. Despite these facts, diagnostic and therapeutic errors are frequently reported in the literature [6].

The aim of this study was to review all published data, available to us, on mismanagement of TACs and $\mathrm{HC}$, in order to understand its causes and help improve the management of these patients. These findings have been reported in preliminary form $\left(3^{\text {rd }}\right.$ European Headache and Migraine Trust International Congress, London, September 2012). 


\section{Review}

We performed a systematic literature search for original articles reporting errors in the diagnosis, therapy or management of TACs and HC. We also looked for review articles to enrich the discussion. In addition, we considered cases of mismanagement that we have observed in our daily practice.

\section{Literature search}

A PubMed database search was performed up to 25 September 2012, using the following "combination of terms:" "cluster headache" OR "paroxysmal hemicrania" OR SUNCT OR "short-lasting unilateral neuralgiform headache attacks with conjunctival injection and tearing" OR SUNA OR "short-lasting unilateral neuralgiform headache attacks with cranial autonomic features" OR "hemicrania continua" OR TAC OR "trigeminal autonomic cephalalgias") AND (error OR pitfall OR misconception OR delay OR "mis-management" OR mismanagement OR undertreatment OR undertreated OR misdiagnosis OR misdiagnosed OR underdiagnosed)". Only articles in English were considered. We also considered articles from the reference lists of the studies found to be relevant, as well as literature known, by the authors, to be relevant.

\section{Data extraction}

Two investigators (M.V and F.A.) separately examined the abstracts of all the articles identified in the literature search. Whenever the article title or abstract suggested that the publication might contain relevant data, the entire manuscript was examined. The following relevant data were extracted from the accepted articles: publication information (authors, years), type of study (case report/series, clinic-based study, population study), sample (number of patients), clinical data (final diagnosis, previous wrong diagnoses and related treatments, number and type of physicians consulted and time to correct diagnosis, incorrect treatments after correct diagnosis). Agreement for data extraction was good. There were only two cases of disagreements that were resolved by consensus.

\section{Results}

The search strategy identified 169 published articles. Of these 169 papers, 13 [6-18] were relevant, while 156 did not meet the criteria (Figure 1). An additional 9 studies [16,19-25] were identified by checking the references of relevant papers and reviews, as well as literature that was known to be relevant by the authors. Finally relevant articles considered for a full text evaluation were 22. All of these 22 articles were included in the analysis. The data on errors in the diagnosis and treatment of TACs or $\mathrm{HC}$ extracted from the case reports/series and clin$\mathrm{ical} /$ population studies considered in this review are summarized in Tables 1, 2, 3 and 4. The cumulative number of patients was 2614 (2593 of them stemmed from the articles found with the search method). Patients with $\mathrm{CH}$ were found to be by far the largest category of mismanaged patients reported in the literature

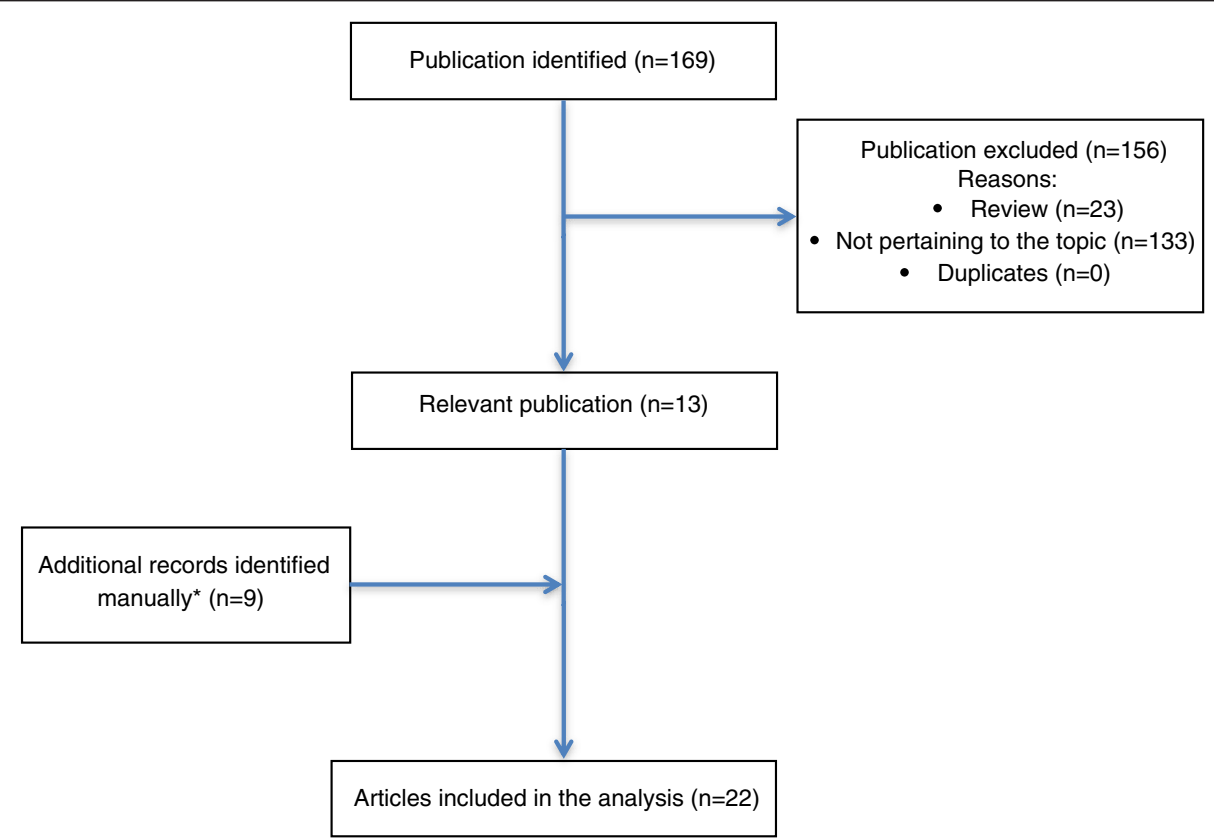

Figure 1 Flow-diagram of the review process. ${ }^{*}$ by checking the references of relevant papers and reviews as well as literature that was known to be relevant by the authors. 
Table 1 Data extracted from case report/series and clinical/population studies dealing with diagnostic/therapeutic errors in $\mathrm{CH}$

\begin{tabular}{|c|c|c|c|c|c|c|c|c|}
\hline Authors & $\begin{array}{l}\text { N. } \\
\text { of } \\
\text { pts }\end{array}$ & Sample & $\begin{array}{l}\text { Methods } \\
\text { of data } \\
\text { acquisition }\end{array}$ & $\begin{array}{l}\text { Diagnostic } \\
\text { delay } \\
\text { (means) }\end{array}$ & Misdiagnoses & $\begin{array}{l}\text { Treatment before } \\
\text { diagnosis of } \mathrm{CH}\end{array}$ & $\begin{array}{l}\text { Number/ type } \\
\text { of physicians } \\
\text { consulted prior } \\
\text { to correct diagnosis }\end{array}$ & $\begin{array}{l}\text { Wrong treatment } \\
\text { after correct } \\
\text { diagnosis }\end{array}$ \\
\hline $\begin{array}{l}\text { Van } \\
\text { Alboom } \\
\text { et al., } \\
2009[6]\end{array}$ & 85 & $\begin{array}{l}\text { Clinic-based } \\
\text { series }\end{array}$ & $\begin{array}{l}\text { 90-item } \\
\text { questionnaire }\end{array}$ & 44.4 mths & $\begin{array}{l}\text { Migraine (45\%), sinusitis (23\%), } \\
\text { tooth/jaw problems ( } 23 \%), \text { TTH } \\
(16 \%), \text { TN }(16 \%) \text {, ophthalmological } \\
\text { problems (10\%), neck problems } \\
(7 \%), \text { nose problems (5\%) }\end{array}$ & $\begin{array}{l}31 \% \text { of pts had invasive } \\
\text { therapy prior to } \mathrm{CH} \\
\text { diagnosis, including dental } \\
\text { procedures }(21 \%) \text { and } \\
\text { sinus surgery }(10 \%)\end{array}$ & $\geq 3$ (in 52\% pts) & $\begin{array}{l}\text { Propranolol (12\%), } \\
\text { amitriptyline (9\%), } \\
\text { carbamazepine } \\
(12 \%)\end{array}$ \\
\hline $\begin{array}{l}\text { Eross et al. } \\
2007[11]\end{array}$ & 1 & $\begin{array}{l}\text { General } \\
\text { population } \\
\text { study (SAMS) }\end{array}$ & Direct interview & NR & Sinus headache & $N R$ & self-diagnosed & NR \\
\hline $\begin{array}{l}\text { Jensen } \\
\text { et al. } 2007 \\
{[26]}\end{array}$ & 85 & $\begin{array}{l}\text { Clinic-based } \\
\text { series§ }\end{array}$ & $\begin{array}{l}\text { Semistructured } \\
\text { telephone } \\
\text { interview }\end{array}$ & $\begin{array}{l}8 \text { yrs (range } \\
0-35 \text { ) for } \\
\text { ECH and } \\
9 \text { yrs (range } \\
0-39 \text { ) for } \\
\text { CCH }\end{array}$ & $N R$ & $\begin{array}{l}\text { Non-medical treatment } \\
\text { was received by } 58 \% \\
\text { (49/85) of the cluster } \\
\text { patients }\end{array}$ & $\begin{array}{l}\text { NR. } 44.7 \%(38 / 85) \\
\text { of the } \mathrm{CH} \text { pts had } \\
\text { previously been } \\
\text { admitted to hospital } \\
\text { due to } \mathrm{CH}\end{array}$ & NR \\
\hline $\begin{array}{l}\text { Schurks } \\
\text { et al. } 2006 \\
\text { [17] }\end{array}$ & 246 & $\begin{array}{l}\text { Clinic- and } \\
\text { non-clinic- } \\
\text { based }\end{array}$ & $\begin{array}{l}\text { Direct interview } \\
\text { (telephone or } \\
\text { face-to-face) or } \\
\text { standardized } \\
\text { mailed } \\
\text { questionnaire }\end{array}$ & NR & $N R$ & $N R$ & NR & $\begin{array}{l}25 \% \text { of patients } \\
\text { used non-first- } \\
\text { choice medication } \\
\text { (such as opioids) }\end{array}$ \\
\hline $\begin{array}{l}\text { Bahra and } \\
\text { Goadsby } \\
2004[8]\end{array}$ & 230 & $\begin{array}{l}\text { Non-clinic- } \\
\text { based (76\%) } \\
\text { and clinic- } \\
\text { based (24\%) }\end{array}$ & $\begin{array}{l}\text { Direct interview } \\
\text { (telephone or } \\
\text { face- to-face) }\end{array}$ & $\begin{array}{l}2.6 \mathrm{yrs} \\
(1990 \mathrm{~s}) \text { to } \\
22.3 \mathrm{yrs} \\
(1960 \mathrm{~s})\end{array}$ & $N R$ & $\begin{array}{l}52 \% \text { of pts who had been } \\
\text { seen by a dentist or ENT } \\
\text { surgeon had an invasive } \\
\text { procedure }\end{array}$ & $\begin{array}{l}\text { Mean } 3 \text { GPs. } 2 / 3 \text { of the pts } \\
\text { seen by another specialist: } \\
\text { dentist }(45 \%) \text {, ENT ( } 27 \%) \text {, } \\
\text { optician (43\%), opht (15\%), } \\
\text { others ( } 7 \%)\end{array}$ & $\begin{array}{l}\text { Beta-blocker (43\%), } \\
\text { pizotifen (32\%), } \\
\text { TCAs (32\%); } \\
\text { alternative therapy } \\
\text { (including } \\
\text { acupuncture } \\
\text { in } 40 \% \text {, herbal } \\
\text { treatment in 31\%, } \\
\text { chiropractic } \\
\text { treatment in 23\%, } \\
\text { homeopathy in } \\
\text { 18\%) }\end{array}$ \\
\hline $\begin{array}{l}\text { Van Vliet } \\
\text { et al. } 2003 \\
\text { [18] }\end{array}$ & 1163 & $\begin{array}{l}\text { Nationwide } \\
\text { study clinic- } \\
\text { and non-clinic- } \\
\text { based } \\
\text { population }\end{array}$ & Questionnaire & $\begin{array}{l}3 \text { yrs (range } \\
1 \text { wk-48 yrs) }\end{array}$ & $\begin{array}{l}\text { Sinusitis }(21 \%) \\
\text { migraine }(17 \%), \\
\text { dental-related pain (11\%) }\end{array}$ & $\begin{array}{l}\text { Tooth extraction (16\%) } \\
\text { and ENT operation (12\%) }\end{array}$ & $\begin{array}{l}\text { Dentists (34\%), ENT } \\
\text { specialists (33\%), and } \\
\text { alternative therapists (33\%) }\end{array}$ & NR \\
\hline $\begin{array}{l}\text { Sjastaad \& } \\
\text { Bakketeig, } \\
2003[19]\end{array}$ & 7 & $\begin{array}{l}\text { General } \\
\text { population } \\
\text { study (Vågå } \\
\text { study) on } \\
\text { headache } \\
\text { epidemiology }\end{array}$ & $\begin{array}{l}\text { Direct interview } \\
\text { plus physical and } \\
\text { neurological } \\
\text { examination }\end{array}$ & $\begin{array}{l}11 \text { yrs (range } \\
<1-28)\end{array}$ & $\begin{array}{l}\text { NR ( } 5 \text { out of } 7 \text { pts had never } \\
\text { consulted a physician) }\end{array}$ & $\begin{array}{l}\text { NR ( } 5 \text { out of } 7 \text { pts had never } \\
\text { consulted a physician) }\end{array}$ & $\begin{array}{l}5 \text { out of } 7 \text { pts had never } \\
\text { consulted a physician }\end{array}$ & NR \\
\hline
\end{tabular}


Table 1 Data extracted from case report/series and clinical/population studies dealing with diagnostic/therapeutic errors in $\mathrm{CH}$ (Continued)

\begin{tabular}{|c|c|c|c|c|c|c|c|c|}
\hline $\begin{array}{l}\text { Klapper } \\
\text { et al. } 2000 \\
\text { [13] }\end{array}$ & 693 & $\begin{array}{l}\text { Internet-based } \\
\text { survey }\end{array}$ & $\begin{array}{l}\text { Internet } \\
\text { questionnaire }\end{array}$ & $6.6 \mathrm{yrs}$ & $\begin{array}{l}3.9 \text { (average number } \\
\text { of incorrect diagnoses } \\
\text { before } \mathrm{CH} \text { ) NOS }\end{array}$ & $\begin{array}{l}5 \% \text { had surgery (mostly } \\
\text { sinus or deviated septum surgery), } \\
\text { other pts were prescribed with } \\
\text { sinus medications }\end{array}$ & $\begin{array}{l}4.3 \text { (3.3 gave an incorrect } \\
\text { diagnosis) }\end{array}$ & $\begin{array}{l}\text { Propranolol }(27.2 \%) \\
\text { amitriptyline } \\
(16.4 \%) \\
\text { cyproheptadine } \\
(2.3 \%)\end{array}$ \\
\hline $\begin{array}{l}\text { Hoffert } \\
1995[12]\end{array}$ & 1 & Case report & Case report & $5 \mathrm{yrs}$ & Dental pain & Extractions of all the teeth & Dentist & $N R$ \\
\hline $\begin{array}{l}\text { Bittar and } \\
\text { Graff- } \\
\text { Radford } \\
1992[9]\end{array}$ & 33 & $\begin{array}{l}\text { Clinic-based } \\
\text { series }\end{array}$ & $\begin{array}{l}\text { Review of clinical } \\
\text { chart }\end{array}$ & $\begin{array}{l}8 \text { yrs } \\
\text { (mean } \\
\text { duration } \\
\text { of pain) }\end{array}$ & NR & $\begin{array}{l}42 \% \text { of pts received inappropriate } \\
\text { dental treatment which was often } \\
\text { irreversible, almost all pts received } \\
\text { different medications (NSAIDs, } \\
\text { opiates, AEDs, TCAs) }\end{array}$ & $\begin{array}{l}\text { Consultant seen before: } \\
72 \% \text { neurologist, } 42 \% \\
\text { dentist, } 27 \% \text { internist, } \\
12 \% \text { ENT, } 9 \% \text { allergist }\end{array}$ & NR \\
\hline
\end{tabular}

CH: cluster headache; TH: tension-type headache; TN: trigeminal neuralgia; wk: week; mths: months; yrs: years; SAMS: The Sinus, Allergy and Migraine Study; ECH: episodic cluster headache; CCH: chronic cluster headache; NSAIDs: non-steroidal antiinflammatory drugs; AEDs: anti-epileptic drugs; TCAs: tricyclic antidepressants. NOS: not otherwise specified; NR: not reported; opht: ophthalmologist. § 100 randomly chosen patients with the initial diagnosis of cluster headache seen at the Department of Neurology, Glostrup Hospital and the Danish Headache Centre between October 1998 and September 2003. 
Table 2 Data extracted from case reports dealing with diagnostic/therapeutic errors in PH

\begin{tabular}{|c|c|c|c|c|c|c|}
\hline Authors & N. of pts & Sample & $\begin{array}{l}\text { Diagnostic } \\
\text { delay }\end{array}$ & Misdiagnoses & $\begin{array}{l}\text { Treatment received } \\
\text { before diagnosis of } \mathrm{PH}\end{array}$ & $\begin{array}{l}\text { Number/type of physicians } \\
\text { consulted prior to correct } \\
\text { diagnosis }\end{array}$ \\
\hline $\begin{array}{l}\text { Alonso } \\
\text { and Nixdorf } \\
2006[20]\end{array}$ & 1 & $\begin{array}{l}\text { Case } \\
\text { report }\end{array}$ & NR & TMD & Splint therapy and bite adjustments & NR \\
\hline $\begin{array}{l}\text { Sarlani er al } \\
2003[16]\end{array}$ & 1 & $\begin{array}{l}\text { Case } \\
\text { report }\end{array}$ & 2 yrs & TN and sinusitis & $\begin{array}{l}\text { Maxillary sinus surgery, } \\
\text { carbamazepine and } \\
\text { prednisone, paracetamol }\end{array}$ & NR \\
\hline $\begin{array}{l}\text { Benoliel } \\
\text { and Sharav } \\
1998[22]\end{array}$ & 7 & $\begin{array}{l}\text { Case } \\
\text { reports }\end{array}$ & $\begin{array}{l}10 \text { mths } \\
\text { (range 1-30) }\end{array}$ & $\begin{array}{l}\text { Pain of dental origin } \\
(4), \operatorname{TMD}(1), \mathrm{CH}(1){ }^{*}\end{array}$ & $\begin{array}{l}2 \text { pts had irreversible treatments } \\
(1 \text { extraction, } 1 \text { RCT), and } 1 \text { pt } \\
\text { received antibiotics }\end{array}$ & $\begin{array}{l}\text { Mostly at least one dental } \\
\text { practitioner }\end{array}$ \\
\hline $\begin{array}{l}\text { Moncada } \\
\text { and Graff-Radford } \\
1995[25]\end{array}$ & $1 \S$ & $\begin{array}{l}\text { Case } \\
\text { report }\end{array}$ & 12 yrs & TMD & $\begin{array}{l}\text { Complete mouth reconstruction } \\
\text { then recommendation to have } \\
\text { condyloplasty }\end{array}$ & $\begin{array}{l}3 \text { neurologists, } 1 \text { dentist, } \\
1 \text { oral surgeon }\end{array}$ \\
\hline $\begin{array}{l}\text { Delcanho and } \\
\text { Graff-Radford } \\
1993 \text { [24] }\end{array}$ & 2 & $\begin{array}{l}\text { Case } \\
\text { report }\end{array}$ & $\begin{array}{l}\text { Case 1: NR; } \\
\text { Case 2: } 3 \text { yrs }\end{array}$ & $\begin{array}{l}\text { Case 1: dental pain, } \\
\text { migraine; Case 2: } \\
\text { TN, TMD }\end{array}$ & $\begin{array}{l}\text { Case 1: RCT, migraine prophylactic } \\
\text { medications; Case 2: phenytoin } \\
100 \text { mg ti.i.d. }\end{array}$ & $\begin{array}{l}\text { Case 1: numerous physicians } \\
\text { including dentist, neurologist, } \\
\text { internal medicine specialist; } \\
\text { Case 2: } 2 \text { dentists, } 1 \mathrm{GP} \text {, } \\
1 \text { ENT specialist }\end{array}$ \\
\hline
\end{tabular}

PH: paroxysmal hemicrania; TMD: temporomandibular disorder; TN: trigeminal neuralgia; CH: cluster headache; mths: months; yrs: years; NR: not reported; RCT: root canal therapy; * in one patient no previous diagnosis were reported; $\S$ together with another 7 indomethacin-responsive headache patients with orofacial pain as the presenting symptom, 2 of whom were chronic paroxysmal hemicrania cases already included in a previous article [24].

(97,3\% of the whole population reported in these studies). Six major studies, conducted in clinical or general population settings $[6,8,13,17,18,26]$, investigated diagnostic and/or therapeutic errors in $\mathrm{CH}$ patients. A study, by Eross et al., identified one patient with $\mathrm{CH}$ and one with $\mathrm{HC}$ in a series of 100 subjects who believed they had sinus headache [11] while Sjaastad \& Bakketeig interviewed 1838 inhabitans (from 18 to 65-year-old) of the Våga commune in the mountainous area of southern Norway. Seven $\mathrm{CH}$ patients were observed, 6 of whom were un-aware of the diagnosis [19]. Apart from one clinical series of $33 \mathrm{CH}$ patients [9] and two made up of 25 and $22 \mathrm{HC}$ patients, respectively [10,15], the remaining articles were reports of single cases or small numbers of patients with TACs or $\mathrm{HC}$ misdiagnosed as other conditions. Data on non-optimal treatment prescribed, even after a correct diagnosis had been established, was available only for $\mathrm{CH}$. This is probably explained by the fact that $\mathrm{PH}$ and $\mathrm{HC}$ are, by definition, indomethacin-responsive headaches, while SUNCT is a very rare syndrome with an extremely low number of reported cases.

\section{Cluster headache}

Although recent decades have seen an improvement in the time taken to diagnose $\mathrm{CH}$ from onset [8], the diagnostic delay for this condition is still too protracted (more than 3 years in the most recent study [6]), as is the number of physicians consulted before arriving at the correct diagnosis (generally at least 3 medical doctors). A high number of misdiagnoses was described, many of which led to unnecessary invasive and irreversible treatments. $\mathrm{CH}$ was most frequently misdiagnosed as: migraine, sinusitis, tooth/jaw problems, and trigeminal neuralgia. Migraine seems to be a particularly frequent misdiagnosis. The different temporal patterns of migraine and $\mathrm{CH}$ attacks should make it possible to distinguish between these two conditions in the typical

Table 3 Data extracted from case reports dealing with diagnostic/therapeutic errors in SUNCT

\begin{tabular}{llllll}
\hline Authors & N. of pts & Sample & $\begin{array}{l}\text { Diagnostic } \\
\text { delay }\end{array}$ & $\begin{array}{l}\text { Misdiagnoses } \\
\text { Treatment received }\end{array}$ & $\begin{array}{l}\text { Number/type of } \\
\text { before diagnosis } \\
\text { of SUNCT }\end{array}$ \\
\hline $\left.\begin{array}{l}\text { Alore et al. } \\
\text { physicians consulted } \\
\text { prior to correct diagnosis }\end{array}\right]$ & 1 & $\begin{array}{l}\text { Case } \\
\text { report }\end{array}$ & $9 \mathrm{yrs}$ & $\begin{array}{l}\mathrm{TN}, \mathrm{CH}, \\
\text { atypical } \\
\text { migraine }\end{array}$ & $\begin{array}{l}\text { carbamazepine, } \\
\text { phenytoin, } \\
\text { propranolol, } \\
\text { indomethacin } \\
\text { and lithium }\end{array}$
\end{tabular}

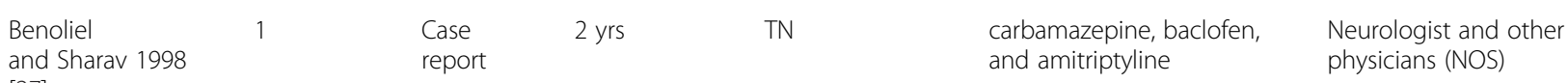

[27]

SUNCT: short-lasting unilateral neuralgiform headache attacks with conjunctival injection and tearing; TN: trigeminal neuralgia; $\mathrm{CH}$ : cluster headache; yrs: years; NR: not reported; NOS: not otherwise specified. 
Table 4 Data extracted from case reports/case series dealing with diagnostic/therapeutic errors in HC

\begin{tabular}{|c|c|c|c|c|c|c|}
\hline Author & N. of pts & Sample & Diagnostic delay & Misdiagnoses & $\begin{array}{l}\text { Treatment received } \\
\text { before diagnosis } \\
\text { of } \mathrm{HC}\end{array}$ & $\begin{array}{l}\text { Number/type } \\
\text { of physicians } \\
\text { consulted prior } \\
\text { to correct diagnosis }\end{array}$ \\
\hline $\begin{array}{l}\text { Cortijo et al. } \\
2012 \text { [10] }\end{array}$ & 22 & $\begin{array}{l}\text { Case series } \\
\text { selected } \\
\text { from a clinical } \\
\text { population } \\
\text { over a } \\
\text { 3-year period }\end{array}$ & $\begin{array}{l}86.1 \pm 106.5 \\
\text { mths (range } \\
3-360 \text { ) }\end{array}$ & None & NR & NR \\
\hline $\begin{array}{l}\text { Prakash et al. } \\
2010 \text { [14] }\end{array}$ & 4 & Case reports & $\begin{array}{l}22 \mathrm{yrs}, \\
3 \mathrm{yrs} \\
2 \mathrm{yrs} \\
15 \mathrm{mths}\end{array}$ & $\begin{array}{l}\text { Atypical facial pain, } \\
\text { atypical odontalgia, } \\
\text { sinusitis, caries, pulpitis, } \\
\text { psychiatric disorder, } \\
\text { chronic migraine }\end{array}$ & $\begin{array}{l}\text { All the patients } \\
\text { had dental extractions } \\
(6 \text { in one pt), } \\
\text { some had sinus } \\
\text { surgery, } \\
\text { root canal treatment }\end{array}$ & $\begin{array}{l}\text { Several dentists, } \\
\text { general physicians, } \\
\text { neurologist and } \\
\text { ENT specialist (NOS) }\end{array}$ \\
\hline $\begin{array}{l}\text { Rossi et al. } \\
2009 \text { [15] }\end{array}$ & 25 & $\begin{array}{l}\text { Case series } \\
\text { selected from a } \\
\text { clinical population } \\
\text { over a } \\
\text { 3-year period }\end{array}$ & $5 \mathrm{yrs}$ & $\begin{array}{l}\text { Migraine (52\%), } \\
\text { CH (28\%), } \\
\text { sinus headache (20\%), } \\
\text { dental pain (20\%), } \\
\text { atypical facial pain (16\%), } \\
\text { stress headache (16\%), } \\
\text { CEH (8\%) }\end{array}$ & $\begin{array}{l}\text { NSAIDs }(92 \%) \text {, triptans } \\
(32 \%) \text {, antidepressants } \\
(32 \%) \text {, and } \\
\text { antiepileptics } \\
(24 \%) .36 \% \text { received } \\
\text { invasive treatments. } \\
36 \% \text { had recourse } \\
\text { to complementary } \\
\text { and alternative } \\
\text { medicine }\end{array}$ & $\begin{array}{l}4.6 \text { (GP } 100 \% \text {, } \\
\text { neurologist } 80 \% \text {, } \\
\text { ENT specialist } 44 \% \text {, } \\
\text { ophthalmologist 40\%, } \\
\text { dentist 32\%, } \\
\text { headache specialist 28\%) }\end{array}$ \\
\hline $\begin{array}{l}\text { Taub et al. } \\
2008[23]\end{array}$ & 2 & Case reports & $\begin{array}{l}1.5 \mathrm{yrs} ; \\
8 \mathrm{mths}\end{array}$ & $\begin{array}{l}\mathrm{TMD} \text {, dental pain, } \\
\mathrm{CH} \text {, migraine, } \mathrm{CPH}\end{array}$ & $\begin{array}{l}\text { Topiramate, } \\
\text { nortriptyline, } \\
\text { melatonin, verapamil, } \\
\text { gabapentin }\end{array}$ & $\begin{array}{l}3 \text { dental practitioners; } \\
1 \text { ENT specialist }\end{array}$ \\
\hline $\begin{array}{l}\text { Eross et al. } \\
2007 \text { [11] }\end{array}$ & 1 & Case report & NR & Sinus headache & NR & NR \\
\hline $\begin{array}{l}\text { Alonso and Nixdorf } \\
2006 \text { [20] }\end{array}$ & 1 & Case report & 6 mths & $\begin{array}{l}\text { Dental pain, } \\
\text { CEH }\end{array}$ & $\begin{array}{l}\text { Dental extraction, } \\
\text { cervical adjustment, } \\
\text { multiple chronic } \\
\text { pain medications }\end{array}$ & $\begin{array}{l}4 \text { (dentist, chiropractor, } \\
\text { general physician, } \\
\text { neurologist) }\end{array}$ \\
\hline $\begin{array}{l}\text { Benoliel et al. } \\
2002[21]\end{array}$ & 1 & Case report & $2 \mathrm{yrs}$ & $\begin{array}{l}\text { Dental pain, } \\
\text { migraine, } \\
\text { CEH }\end{array}$ & $\begin{array}{l}\text { Dental treatment } \\
\text { (NOS), } \\
\text { intensive } \\
\text { physiotherapy, } \\
\text { paracetamol, } \\
\text { propranolol, } \\
\text { diazepam, ergotamine } \\
\text { combination, } \\
\text { diclofenac sodium }\end{array}$ & $\begin{array}{l}3 \text { (neurologist, dentist, } \\
\text { ENT specialist) }\end{array}$ \\
\hline
\end{tabular}

HC: hemicrania continua; $\mathrm{CH}$ : cluster headache; $\mathrm{CEH}$ : cervicogenic headache; TMD: temporomandibular disorder; $\mathrm{CPH}$ : chronic paroxysmal hemicrania; mths: months; yrs: years; NR: not reported; NOS: not otherwise specified.

case, but if this aspect is not reported by the patient or thoroughly investigated by the physician, confusion may arise, given that many other features of these headaches can overlap. Migraine pain is frequently severe in intensity and unilateral in $2 / 3$ of patients [28]. In about $56 \%$ of migraine patients at least one CAS (i.e. lacrimation or conjunctival injection) is present during attacks [29]. Moreover, typical migraine features are often associated with $\mathrm{CH}$ attacks. A study of a large cohort of German $\mathrm{CH}$ patients found that $\mathrm{CH}$ attacks were associated with photophobia or phonophobia in $61.2 \%$ and with nausea and vomiting in $27.8 \%$, while migraine aura preceded $\mathrm{CH}$ attacks in almost a quarter of the patients [17].
Unfortunately, the ICHD-II fails to mention (either in the diagnostic criteria or in the definitions and comments) that CAS may be present in migraine and that nausea, vomiting, and photo/phonophobia may be present in $\mathrm{CH}$. For clinicians, it is helpful to note that photo- and phonophobia tend to be unilateral in TACs and $\mathrm{HC}$ while they are bilateral in migraine [28,30], moreover nausea and vomiting are generally more frequent in migraine than in $\mathrm{CH}$ (especially if they occur together) [31]. Another feature that might increase the risk of misdiagnosing $\mathrm{CH}$ as migraine is the possibility of the pain switching sides between attacks or cluster periods [18]. Many physicians, even headache specialists, 
are not aware that this can happen in $\mathrm{CH}$. Indeed, according to the diagnostic criteria for $\mathrm{CH}$ (ICHD-II, code 3.1) the pain is unilateral; furthermore, the description paragraph states that it is "strictly unilateral" while the comments section specifies that the "pain almost invariably recurs on the same side during an individual cluster period" [1]. Yet, up to $14 \%$ of $\mathrm{CH}$ patients may experience a side shift of pain during a cluster period, and $18 \%$ may have side shifts from one cluster period to the next [32]. A previous diagnosis of tooth/jaw problems is likely to be found in the history of $\mathrm{CH}$ patients, as $37 \%$ to $50 \%$ of them reported that the pain radiated to the lower jaw, upper jaw or cheek $[6,18,32]$. This comes from the fact that patients with $\mathrm{CH}$ often describe the pain as emanating from the midfacial region, which might be interpreted as pain originating from the teeth, jaws or temporomandibular joints. However the presence of unilateral attacks associated with relevant ipsilateral CASs that remit spontaneously within 2-3 hours even if untreated, and that relapse with a clock-like periodicity are strong clues for $\mathrm{CH}$. Sinus headache $(\mathrm{SH})$ is another misdiagnosis often encountered in clinical practice. According to studies on clinic-based and clinic-based plus non-clinic-based $\mathrm{CH}$ populations, this misdiagnosis is made in between $21 \%$ [18] and 23\% [6] of $\mathrm{CH}$ patients. The Sinus, Allergy and Migraine Study - SAMS [11], which, adopting a different perspective, investigated 100 individuals recruited from the general population who believed they had $\mathrm{SH}$, found one who fulfilled the diagnostic criteria for $\mathrm{CH}$. These errors are probably due to the pain localization in $\mathrm{CH}$ (frontal region and upper face) and the fact that the picture typically includes CAS referred to the nose, e.g. rhinorrhea/nasal obstruction. However, whereas nasal discharge in $\mathrm{SH}$ is thick, purulent, malodorous and frequently accompanied by systemic symptoms such as fever, chills and sweats, in $\mathrm{CH}$ it is clear and fluid [1]. Another clinical feature strongly suggesting a diagnosis of $\mathrm{CH}$ is a clock-like regularity of attacks. $\mathrm{CH}$ patients are also often wrongly diagnosed with trigeminal neuralgia (TN). Even though this scenario has been clearly reported by just one study (in which $16 \%$ of $\mathrm{CH}$ patients had previously been diagnosed with TN), [6] it is a situation that we have frequently encountered in our clinical practice. While the localization of the pain and its duration may, to an extent, be considered somehow similar (although duration it is a matter of seconds in TN versus many minutes in $\mathrm{CH}$ ), there are many differences between the two conditions that should aid in the differential diagnosis. These include the presence of CAS, the clock-like periodicity of the attacks, and the presence of nocturnal attacks in $\mathrm{CH}$ (but not in $\mathrm{TN}$ ) and the presence of trigger points (only in $\mathrm{TN}$ ). Nevertheless, TN is, for some reason, the first disorder that many non- headache specialists think of when faced with a patient with a recurrent facial pain condition. Headache specialists should also bear in mind the existence of cluster-tic syndrome, a rare condition characterized by coexistence of $\mathrm{CH}$ and $\mathrm{TN}[33,34]$.

With regard to treatment, many patients, in the course of the long diagnostic work-up of their $\mathrm{CH}$, were administered inappropriate therapies (quite often invasive and irreversible, i.e. dental procedures and ENT surgery). Moreover, even after the correct diagnosis, many of these patients were still prescribed with treatments not considered first-line options for $\mathrm{CH}$ according to the international guidelines [5] (e.g. acute treatments such as opioids or oral triptans or preventive treatment such as propranolol, amitriptyline, carbamazepine and cyproheptadine). We are also aware, from clinical reports at congresses and from our personal observations, of instances in which other non-first-line medications, such as flunarizine or single, high-dose systemic steroid infusion for preventive treatment and indomethacin for acute treatment, were prescribed in $\mathrm{CH}$ patients. The above medications have been found to be ineffective in clinical trials [35,36]. Finally, up to $63 \%$ of $\mathrm{CH}$ sufferers used alternative therapies without finding any of them consistently effective [32].

\section{Paroxysmal hemicrania}

Although our literature review revealed few case series and case reports considering diagnostic pitfalls in $\mathrm{PH}$, this condition appears to be most frequently misdiagnosed as dental pathologies. The severe intensity of the pain and its location in the cheek, jaw and maxillary areas in some attacks of $\mathrm{PH}$ (that in $1 / 3$ of the cases can be pulsating in quality), may explain this confusion with dental-related pain [22]. However, the short duration of the attacks and the presence of CAS should lead the physician to the correct diagnosis. The localization of $\mathrm{PH}$ in the temporal, maxillary and occasionally in the ear regions, along with a certain, ipsilateral masticatory muscle tenderness, can lead to its misdiagnosis as pain associated with temporomandibular disorder (TMD) [37]. Yet, a diagnosis of TMD requires the presence of at least one of the following symptoms and signs: pain precipitated by jaw movements and/or chewing of hard /or tough food, reduced range of or irregular jaw opening, and tenderness of the joint capsule(s) of one or both TMJs [1]. Moreover, differences in the intensity of the pain (excruciating in $\mathrm{PH}$ versus mild-to-moderate aching pain in TMD) should guide the clinician to the correct diagnosis [37]. The excruciating intensity of $\mathrm{PH}$ pain, which also can involve the territories of the second and even third trigeminal branches, and its intermittent temporal pattern may result in an incorrect diagnosis of trigeminal 
neuralgia $(\mathrm{TN})$, especially in the ca. $10 \%$ of $\mathrm{PH}$ patients in whom attacks can be precipitated by mechanical triggers [38]. However, the triggers in the two conditions differ: in $\mathrm{PH}$, attacks can be precipitated by head flexion or rotation or external pressure over the $\mathrm{C} 2$ root, the transverse processes of $\mathrm{C} 4-\mathrm{C} 5$, or the greater occipital nerve on the symptomatic side [38], whereas in TN they can be triggered by actions such as washing the face, shaving, smoking, talking and/or brushing the teeth, or by touching certain small areas in the nasolabial fold and/or chin [1,39]. Unfortunately, the ICHD-II mentions trigger factors only in TN. Had it also mentioned their role in $\mathrm{PH}$, the misdiagnosis rate might be lower. Other features making it possible to differentiate between these two conditions are CAS (present in $\mathrm{PH}$, absent in the majority of $\mathrm{TN}$ cases, with exception for $\mathrm{TN}$ of the first branch), the duration of the pain (from a few seconds to 2 minutes in TN versus $2-30$ minutes in $\mathrm{PH}$ ), and the nocturnal occurrence of attacks (possible in $\mathrm{PH}$, awakening the patient from sleep, but unusual in $\mathrm{TN}$ ) [22]. The possibility of $\mathrm{PH}$-tic syndrome, similar to cluster-tic syndrome, should also be borne in mind, even though it is a very rare condition [40]. Cervicogenic headache (CEH) is a unilateral side-locked headache associated with evidence of cervical involvement (provocation of pain by movement of the neck or by pressure on the neck) [41]. CEH seems to be the most frequently occurring of the hitherto well-known, unilateral headaches. i.e. at 2.2\% [42]. Because PH is also a unilateral side-locked headache that can be triggered by neck movement/external pressure in which the pain sometimes involves the neck and occipital areas [38], it can be mistaken for $\mathrm{CEH}$. Although this review did not identify published cases of $\mathrm{PH}$ clearly misdiagnosed as $\mathrm{CEH}$, in the authors' clinical experience this wrong diagnosis can occur. Elements to consider in order to distinguish $\mathrm{PH}$ from $\mathrm{CEH}$ are: associated CAS (present in $\mathrm{PH}$, absent in $\mathrm{CEH}$ ), the intensity of the pain (severe or excruciating in $\mathrm{PH}$, moderate in $\mathrm{CEH}$ ), and its temporal pattern (frequent, short-lasting attacks in $\mathrm{PH}$, versus pain episodes of varying duration or fluctuating continuous pain in $\mathrm{CEH}$ ). A complete response to indomethacin administration and/or a lack of efficacy of root-nerve blockade further corroborate a diagnosis of PH. Benoliel and Sharav considered the difficulty of differentiating $\mathbf{C H}$ from $\mathrm{PH}$, given the broad clinical overlap between the two conditions, although they did not report specific cases of misdiagnosis [22]. In this regard, it is helpful to remember some differences between the two conditions such as frequency and duration of attacks (more frequent and shorter in $\mathrm{PH}$ than in $\mathrm{CH}$ ), the sex dominance (male in $\mathrm{CH}$ and female in $\mathrm{PH}$ ) and the patient behavior during the attacks (restless/agitated in $\mathrm{CH}$ and generally more quiet in $\mathrm{PH}$ ). A positive response to indomethacin administration (the Indotest) is a sine qua non for the diagnosis of $\mathrm{CPH}$ [35]. A properly administered Indotest would prevent not only an incorrect diagnosis, but also the possibility to be prescribed with inappropriate treatment, pharmacological or surgical (multiple tooth extractions, stellate ganglion blocks, cervical sympathetic blocks, trigeminal sensory root section, infraorbital nerve section, sphenopalatine anesthetic injection and gangliectomy, infiltration of the point of Arnold, ethmoidosphenectomy) [25,38].

\section{SUNCT}

We identified only two published cases of SUNCT misdiagnosed as other conditions; in both cases TN was one of the wrongly diagnosed conditions. Differentiating SUNCT from TN can be challenging, because the conditions have significantly overlapping clinical phenotypes. The main aspects to take into account include: autonomic features (prevalent in SUNCT and rare in TN), the localization of the pain (V1 in SUNCT and $\mathrm{V} 2 / 3$ in TN), and refractory periods (absent in SUNCT and present in TN) [43]. Primary stabbing headache (PSH) is an idiopathic condition, commonly experienced also by people with other primary headaches such as migraine (about 40\%) and $\mathrm{CH}$ (about 30\%). $\mathrm{PSH}$ is characterized by unilateral but erratic, moderate-to-severe, jabbing or stabbing pain, lasting from a fraction of a second to 3 seconds [1] or more (in the Våga study there were also cases of "prolonged jabs" that may last $10-120 \mathrm{sec})$. PSH can be differentiated from SUNCT on the basis of the site and radiation of the pain (that often varies from one attack to the other), the lack of CAS and triggers [44], and the shorter duration of the attacks (usually less than five seconds, versus a mean of 49 seconds in SUNCT) [45]. SUNCT can also be misdiagnosed as dental pain. A review of TACs from the perspective of their implications for dentistry reported cases in which patients with SUNCT, in addition to experiencing facial pain, complained of pain radiating to adjacent teeth [37]. This resulted in therapeutic interventions for dental pain, such as extractions, occlusal splints and incorrect drug treatments. Other therapeutic errors have stemmed from incorrect diagnosis of SUNCT as primary headache syndromes such as $\mathrm{TN}$, atypical migraine, and $\mathrm{CH}$ (see Table 3).

\section{Hemicrania continua}

There are several reported cases of HC mimicking dental pain or TMD. According to a review and case reports on $\mathrm{HC}$, patients can mistake their $\mathrm{HC}$ symptoms for toothache or TMD [14,46]. Rossi et al. described 25 patients fulfilling the ICHD-II criteria for HC selected among 1612 subjects attending an Italian Headache Center over a three-year period. Fifty-two percent of 
these patients had previously been misdiagnosed with migraine [15]. This is probably due to the fact that certain migraine features (pain-related ones and associated symptoms) can also occur in HC. Indeed the $40 \%$ of the $\mathrm{HC}$ patients described by Rossi et al. met the ICHD-II criteria for migraine during $\mathrm{HC}$ pain exacerbations [15]. A less common feature of $\mathrm{HC}$ that might easily lead to misdiagnosis is the occurrence, reported in four patients, of migraine aura before or during the pain exacerbation [47]. Seven of the $25 \mathrm{HC}$ patients described by Rossi et al. had previously been incorrectly diagnosed with $\mathbf{C H}$ [15]. According to the authors, this was probably due to the fact that $32 \%$ of their $\mathrm{HC}$ patients fulfilled the diagnostic criteria for $\mathrm{CH}$ during pain exacerbations, and also to the tendency of $\mathrm{HC}$ patients to describe only their most severe headache, failing to report the presence of a persistent low-level headache. This might lead to a wrong diagnosis: physicians who investigating a case of episodic head/facial pain syndrome should always seek to establish whether the patient also experiences a lower intensity pain. We identified four cases (reported in three different papers $[15,20,21])$ of HC patients wrongly diagnosed with CEH. Both $\mathrm{CEH}$ and $\mathrm{HC}$ are side-locked unilateral headaches with a continuous temporal pattern (CEH can have either an episodic or a continuous fluctuating pattern) that can be accompanied by signs and symptoms of neck involvement (always present in $\mathrm{CEH}$, and common in $\mathrm{HC}$ too [48]) and by migrainous features [48] (although the degree and the frequency of these associated features is different - i.e. the mean ratio migraine/CEH for the presence of other symptoms were almost 5 for nausea, 4 for throbbing quality of pain, ca 3.5 for photophobia [42]). The response to the Indotest and/or to anesthetic blockade can definitively differentiate between these two similar conditions [35]. SH as a misdiagnosis of $\mathrm{HC}$ was reported not only by Rossi et al. [15] but also in the Sinus, Allergy and Migraine Study [11]. The most important clinical difference concerns the nasal discharge (clear and fluid in $\mathrm{HC}$ but "infectious" in $\mathrm{SH}$ ). In the routine clinical work-up, nasal endoscopic data, CT and/or MRI imaging and/or laboratory evidence of acute or acute-on-chronic rhinosinusitis are needed, diagnostically [1]. Therapeutic errors in HC are always secondary to misdiagnosis of the condition (as in $\mathrm{PH}$, indomethacin response is a diagnostic criterion of $\mathrm{HC}$ ) and patients can undergo not only wrong pharmacological treatments, but also unnecessary dental extractions, TMD or ENT surgery, physical therapy, or complementary and alternative medicine therapies $[15,20,21,23]$.

\section{Discussion and conclusions}

In this study, we set out to collect, for the first time, all the original papers referring to diagnostic and therapeutic errors in TACs and HC. Our Medline search strategy detected 13 original articles out of the overall 22 papers that we were able to find in literature (including also the manual search) and that were focused on this topic. These 13 manuscripts included all the major studies conducted in this area; indeed, 2593 of the total of 2614 patients were from studies reported in these 13 manuscripts. On this basis, the Pubmed search strategy that we set up can be deemed satisfactory. On the other hand, we cannot exclude the possibility that our search methods missed some articles not specifically focusing on this topic, but nevertheless containing data of interest for our purposes. Moreover, the likelihood that all data on errors in diagnosis and/or management of these conditions cannot be found in the literature is overwhelming. Not all physicians are inclined to report and/or search and publish "errors". This is true not just for TACs and HC, but generally for all diseases. Nevertheless we have tried to supplement the relatively scarce literature data by also reporting our own experiences in clinical practice, and the experiences of colleagues (reported to us directly or at conferences).

A novel aspect of this study was the attempt to identify the causes of errors (and the context in which they occurred) in order to understand them better and offer advice on how they might be avoided.

Some of the diagnostic errors identified in this study derived from the fact that non-headache specialists (not only general physician but also ENT surgeons, ophthalmologists and dentists) often are unaware of the less common nosological entities. There is thus a need for specific training in this regard. However, the reported literature also shows that neurologists and headache specialists are liable to making diagnostic mistakes. There may be different reasons for this. The fact that the best diagnostic tool for headache disorders, ICHD-II (well-known and frequently consulted by headache specialists), fails to mention certain clinical features shared by TACs and HC, such as the localization of the pain (which frequently involves the midface, teeth and TMJ, and can switch sides) and associated symptoms (gastrointestinal, photo/phonophobia, aura, etc.) might lead even headache experts to making wrong diagnoses. To reduce the frequency of diagnostic errors, we suggest that these elements should be included in the forthcoming ICHD-III, at least in the comments sections.

The majority of the observed therapeutic errors are due to misdiagnoses. However, even correct diagnoses are no guarantee of an optimal therapeutic approach. For example, drugs not constituting the first-line treatment were reportedly prescribed for correctly diagnosed $\mathrm{CH}$ [6], in spite of the availability of updated international therapeutic guidelines for this condition [5].

In conclusion, the results of this review underline the need, alongside the current useful international diagnostic 
criteria and therapeutic guidelines, for more education concerning TACs and $\mathrm{HC}$, in order to improve their recognition and management.

\section{Competing interests}

The authors declare that they have no competing interests.

\section{Authors' contributions}

MV and FA designed this review. MV performed the electronic literature search. MV, FA and OS performed the manual search. MV and FA carried out the data extraction. All authors have made substantial contributions to analysis and interpretation of data, have been involved in drafting the manuscript or revising it critically for important intellectual content. All authors read and approved the final manuscript.

\section{Acknowledgments}

This review was inspired by the talk given by F.A. at the Master in Headache Medicine, "La Sapienza" University, Rome, Italy, February 2012, Academic Year 2011-2012. This study was carried out in collaboration with UCADH, University Consortium for Adaptive Disorders and Head pain, University of Pavia, Italy.

\section{Author details}

${ }^{1}$ Headache Science Center-C. Mondino National Institute of Neurology Foundation, IRCCS, Via Mondino 2, Pavia 27100, Italy. ${ }^{2}$ Department of Brain and Behaviour, University of Pavia, Pavia, Italy. ${ }^{3}$ Department of Neurology, St. Olavs Hospital, Trondheim University Hospitals (NTNU), Trondheim, Norway.

Received: 2 January 2013 Accepted: 9 February 2013

Published: 18 February 2013

\section{References}

1. Headache Classification Subcommittee of the International Headache $\mathbf{S}$ (2004) The international classification of headache disorders: 2nd edition. Cephalalgia 24(Suppl 1):9-160

2. Goadsby PJ, Cittadini E, Cohen AS (2010) Trigeminal autonomic cephalalgias: paroxysmal hemicrania, SUNCT/SUNA, and hemicrania continua. Semin Neurol 30(2):186-191

3. Pareja JA, Vincent M, Antonaci F, Sjaastad O (2001) Hemicrania continua: diagnostic criteria and nosologic status. Cephalalgia 21(9):874-877

4. Sjaastad O, Vincent M (2010) Indomethacin responsive headache syndromes: chronic paroxysmal hemicrania and Hemicrania continua. How they were discovered and what we have learned since. Funct Neurol 25(1):49-55

5. May A, Leone M, Afra J, Linde M, Sandor PS, Evers S, Goadsby PJ, Force ET (2006) EFNS guidelines on the treatment of cluster headache and other trigeminal-autonomic cephalalgias. Eur J Neurol 13(10):1066-1077

6. Van Alboom E, Louis P, Van Zandijcke M, Crevits L, Vakaet A, Paemeleire K (2009) Diagnostic and therapeutic trajectory of cluster headache patients in Flanders. Acta Neurol Belg 109(1):10-17

7. Alore PL, Jay WM, Macken MP (2006) SUNCT syndrome: short-lasting unilateral neuralgiform headache with conjunctival injection and tearing. Semin Ophthalmol 21(1):9-13

8. Bahra A, Goadsby PJ (2004) Diagnostic delays and mis-management in cluster headache. Acta Neurol Scand 109(3):175-179

9. Bittar G, Graff-Radford SB (1992) A retrospective study of patients with cluster headaches. Oral Surg Oral Med Oral Pathol 73(5):519-525

10. Cortijo E, Guerrero AL, Herrero S, Mulero P, Munoz I, Pedraza MI, Penas ML, Rojo E, Campos D, Fernandez R (2012) Hemicrania continua in a headache clinic: referral source and diagnostic delay in a series of 22 patients. J Headache Pain 13(7):567-569

11. Eross E, Dodick D, Eross M (2007) The sinus, allergy and migraine study (SAMS). Headache 47(2):213-224

12. Hoffert MJ (1995) Headaches that masquerade as dental pain. J Mass Dent Soc 44(1):33-35

13. Klapper JA, Klapper A, Voss T (2000) The misdiagnosis of cluster headache: a nonclinic, population-based, Internet survey. Headache 40(9):730-735

14. Prakash S, Shah ND, Chavda BV (2010) Unnecessary extractions in patients with hemicrania continua: case reports and implication for dentistry. J Orofac Pain 24(4):408-411
15. Rossi P, Faroni J, Tassorelli C, Nappi G (2009) Diagnostic delay and suboptimal management in a referral population with hemicrania continua. Headache 49(2):227-234

16. Sarlani E, Schwartz AH, Greenspan JD, Grace EG (2003) Chronic paroxysmal hemicrania: a case report and review of the literature. J Orofac Pain 17(1):74-78

17. Schurks M, Kurth T, de Jesus J, Jonjic M, Rosskopf D, Diener HC (2006) Cluster headache: clinical presentation, lifestyle features, and medical treatment. Headache 46(8):1246-1254

18. van Vliet JA, Eekers PJ, Haan J, Ferrari MD, Dutch RSG (2003) Features involved in the diagnostic delay of cluster headache. J Neurol Neurosurg Psychiatry 74(8):1123-1125

19. Sjaastad O, Bakketeig LS (2003) Cluster headache prevalence. Vaga study of headache epidemiology. Cephalalgia 23(7):528-533

20. Alonso AA, Nixdorf DR (2006) Case series of four different headache types presenting as tooth pain. J Endod 32(11):1110-1113

21. Benoliel R, Robinson S, Eliav E, Sharav Y (2002) Hemicrania continua J Orofac Pain 16(12455433):317-325

22. Benoliel R, Sharav Y (1998) Paroxysmal hemicrania. Case studies and review of the literature. Oral Surg Oral Med Oral Pathol Oral Radiol Endod 85 (3):285-292.

23. Taub D, Stiles A, Tucke AG (2008) Hemicrania continua presenting as temporomandibular joint pain. Oral Surg Oral Med Oral Pathol Oral Radiol Endod 105(2):e35-e37

24. Delcanho RE, Graff-Radford SB (1993) Chronic paroxysmal hemicrania presenting as toothache. J Orofac Pain 7(3):300-306

25. Moncada E, Graff-Radford SB (1995) Benign indomethacin-responsive headaches presenting in the orofacial region: eight case reports. J Orofac Pain 9(3):276-284

26. Jensen RM, Lyngberg A, Jensen RH (2007) Burden of cluster headache. Cephalalgia 27(6):535-541

27. Benoliel R, Sharav Y (1998) SUNCT syndrome: case report and literature review. Oral Surg Oral Med Oral Pathol Oral Radiol Endod 85(2):158-161

28. Sjaastad O (1992) Cluster headache syndrome. W.B. Saunders, London

29. Lai TH, Fuh JL, Wang SJ (2009) Cranial autonomic symptoms in migraine: characteristics and comparison with cluster headache. J Neurol Neurosurg Psychiatry 80(10):1116-1119

30. Irimia P, Cittadini E, Paemeleire K, Cohen AS, Goadsby PJ (2008) Unilateral photophobia or phonophobia in migraine compared with trigeminal autonomic cephalalgias. Cephalalgia 28(6):626-630

31. Ekbom K (1970) A clinical comparison of cluster headache and migraine. Acta Neurol Scand 48(Suppl 41):1-48

32. Bahra A, May A, Goadsby PJ (2002) Cluster headache: a prospective clinical study with diagnostic implications. Neurology 58(3):354-361

33. Green M, Apfelbaum R (1978) Cluster-tic syndrome headache. Headache $18: 112$

34. Solomon S, Apfelbaum RI, Guglielmo KM (1985) The cluster-tic syndrome and its surgical therapy. Cephalalgia 5(2):83-89

35. Antonaci F, Costa A, Ghirmai S, Sances G, Sjaastad O, Nappi G (2003) Parenteral indomethacin (the INDOTEST) in cluster headache. Cephalalgia 23(3):193-196

36. Antonaci F, Costa A, Candeloro E, Sjaastad O, Nappi G (2005) Single high-dose steroid treatment in episodic cluster headache. Cephalalgia 25(4):290-295

37. Balasubramaniam R, Klasser GD, Delcanho R (2008) Trigeminal autonomic cephalalgias: a review and implications for dentistry. J Am Dent Assoc 139 (12):1616-1624

38. Antonaci F, Sjaastad O (1989) Chronic paroxysmal hemicrania (CPH): a review of the clinical manifestations. Headache 29(10):648-656

39. Silberstein SD, Lipton RB, Dodick D, Wolff HG (2008) Wolff's headache and other head pain, 8th edn. Oxford University Press, Oxford, New York

40. Mathew NT (2010) Cluster headache and other trigeminal autonomic cephalalgias diagnostic criteria. Handb Clin Neurol 97:421-429

41. Sjaastad O, Fredriksen TA, Pfaffenrath V (1990) Cervicogenic headache: diagnostic criteria. Headache 30(11):725-726

42. Sjaastad O (2008) Cervicogenic headache: comparison with migraine without aura; vaga study. Cephalalgia 28(Suppl 1):18-20

43. Sjaastad O, Kruszewski P (1992) Trigeminal neuralgia and "SUNCT" syndrome: similarities and differences in the clinical pictures. An overview. Funct Neurol 7(2):103-107

44. Pareja JA, Sjaastad O (2010) Primary stabbing headache. Handb Clin Neurol 97:453-457 
45. Pareja JA, Shen JM, Kruszewski P, Caballero V, Pamo M, Sjaastad O (1996)

SUNCT syndrome: duration, frequency, and temporal distribution of attacks. Headache 36(3):161-165

46. Peres MF, Valenca MM, Goncalves AL (2009) Misdiagnosis of hemicrania continua. Expert Rev Neurother 9(9):1371-1378

47. Peres MF, Siow HC, Rozen TD (2002) Hemicrania continua with aura. Cephalalgia 22(3):246-248

48. Peres MF, Silberstein SD, Nahmias S, Shechter AL, Youssef I, Rozen TD, Young WB (2001) Hemicrania continua is not that rare. Neurology 57(6):948-951

doi:10.1186/1129-2377-14-14

Cite this article as: Viana et al.: Diagnostic and therapeutic errors in trigeminal autonomic cephalalgias and hemicrania continua: a systematic review. The Journal of Headache and Pain 2013 14:14.

Submit your manuscript to a SpringerOpen ${ }^{\circ}$ journal and benefit from:

- Convenient online submission

- Rigorous peer review

- Immediate publication on acceptance

- Open access: articles freely available online

- High visibility within the field

- Retaining the copyright to your article

Submit your next manuscript at $>$ springeropen.com 